\title{
Synthesis and Properties of AABAAB-Type Macroheterocyclic Compounds with Fragments of 1,2,4- and 1,3,4-Thiadiazole
}

\author{
Yuliya V. Butina, Elena A. Danilova, ${ }^{\circledR}$ and Tatiana V. Kudayarova \\ Ivanovo State University of Chemistry and Technology, International Research Laboratory of Nanomaterials of Research \\ Institute of Macroheterocyclic Compounds, 153000 Ivanovo, Russian Federation \\ ${ }^{\circledR}$ Corresponding authorE-mail: danilova@isuct.ru
}

\begin{abstract}
New macroheterocyclic compounds of AABAAB-type with expanded coordination cavity were obtained by condensation of diamino derivatives of thiadiazoles (fragment A) and 1,3-diiminoisoindoline or tert-butyldiiminoisoindoline (fragment B). The compounds were characterized by mass spectrometry, IR, UV-vis, ${ }^{1} H$ NMR spectroscopy. Quantum chemical calculations of model compound were carried out by the density functional theory (B3LYP, 6-31G (d, p)) to determine steric and electronic structure.
\end{abstract}

Keywords: Thiadiazoles, diamino derivatives, 1,3-diiminoisoindoline, AABAAB macroheterocycles, spectral study, DFT calculations.

\section{Синтез и свойства макрогетероцикАических соеАинений ААВААВ-типа с фрагментами 1,2,4- и 1,3,4-тиадиазолов}

\author{
Ю. В. Бутина, Е. А. Аанилова, ${ }^{@}$ Т. В. Кудаярова \\ Ивановский государственный химико-технологический университет, НИИ макрогетерочиклических соединений, \\ 153000 Иваново, Россия \\ @E-mail: danilova@isuct.ru
}

\begin{abstract}
Конденсаџией диаминопроизводных тиадиазолов (фрагмент А) и 1,3-дииминоизоиндолина или третбутилдииминоизоиндолина (фрагмент B) получены новые макрогетероииклические соединения АABAAB-типа с увеличенной координационной полостью.
\end{abstract}

Ключевые слова: Тиадиазол, диаминопроизводные, 1,3-дииминоизоиндолин, макрогетероциклы ААВААВ типа, спектральное исследование, DFT расчет.

\section{Introduction}

Both modification of peripheral fragments of molecules and variation of the size of the coordination cavity of macrocyclic compounds allow for the development of therapeutic agents for photodynamic cancer therapy and viral disease, ${ }^{[1,2]}$ as well as materials with unique optical, magnetic, semiconductor properties. ${ }^{[3,4]}$ Macroheterocyclic compounds (Mc) with expanded coordination cavities comprised of 6 smaller heterocyclic moieties that are linked to each other via aza-bridges are fundamentally interesting. ${ }^{[5-8]}$ However, purification of similar compounds is difficult what can negatively affect their basic research and application.
Mc compounds containing three thiadiazole and three isoindoline fragments have been widely studied. ${ }^{[9,10]}$ Their structures were confirmed by gas electron diffraction and X-ray crystallographic analysis. ${ }^{[11-14]}$ The compounds exhibit an expanded cavity which is able to contain up to three transition metal atoms, ${ }^{[8,15,16]}$ possess high thermal stability, ${ }^{[17]}$ show interesting electrochemical and photophysical properties $^{[14,18]}$ and are of particular interest as objects of supramolecular chemistry.

Recently data were published on the synthesis and the structures of AABAAB-type Mc compounds, containing two fragments of the binuclear diamine bis(5-amino-1,2,4triazol-3-yl)methane (AA), and two residues of isoindoline 
connected with each other via aza-bridges and methylene groups. ${ }^{[19]}$ The current work is considered to be a continuation of research ${ }^{[19]}$ and its main objective is the synthesis of new macroheterocyclic compounds of AABAAB-type with expanded coordination cavities of different composition.

\section{Experimental}

IR spectra were collected with a AVATAR 360 FT-IR spectrometer. UV-vis spectra were recorded with a HITACHI U-2001 spectrophotometer. ${ }^{~} \mathrm{H}$ NMR spectra were measured with a Bruker DRX-500 spectrometer. ESI-MS mass-spectra were carried out with a Bruker Reflex III instrument, MALDI-TOF mass-spectra were collected with a AXIMA Confidence (SHIMADZU). Column chromatography was performed on silica gel Merck-60 (230-400 mesh, $60 \AA$ ). TLC was performed on aluminum sheets precoated with silica gel $60 \mathrm{~F}_{254}$ (E. Merck).

1,3-Diiminoisoindoline (1). The synthesis was carried out following a literature procedure. ${ }^{[20]}$ Yield: $1.88 \mathrm{~g}(83 \%) . \mathrm{T}_{\text {melt }}=$ $188-190{ }^{\circ} \mathrm{C}$. IR (KBr) $v_{\max } \mathrm{cm}^{-1}: 3416(\mathrm{~N}-\mathrm{H} \mathrm{v}), 3287,1636(\mathrm{C}=\mathrm{N}$ v), 1541 (C-C v), 1443, 1317, 1262, 1158, 1135, 1069, 868, 820, 774, 699, 546.

5-tert-Butyl-1,3-diiminoisoindoline (2). The compound was prepared by known method. ${ }^{[21]}$ Yield: $0.7 \mathrm{~g}(64 \%) . \mathrm{T}_{\text {melt }}=210-212{ }^{\circ} \mathrm{C}$. IR (KBr) $v_{\max } \mathrm{cm}^{-1}: 3408(\mathrm{~N}-\mathrm{H} \mathrm{v}), 2965(\mathrm{C}-\mathrm{H} \mathrm{d}), 1635(\mathrm{C}=\mathrm{N} \mathrm{v})$, 1541 (C-C v), 1456, 1316, 1272, 1140, 1079, 843, 676, 536.

3,5-Diamino-1,2,4-thiadiazole (3). The synthesis was carried out as described by literature procedure. ${ }^{[22]}$ Yield: $0.94 \mathrm{~g}(96 \%)$. $\mathrm{T}_{\text {melt }}=166-168{ }^{\circ} \mathrm{C}$. IR (KBr) $v_{\max } \mathrm{cm}^{-1}: 3414(\mathrm{~N}-\mathrm{H} \mathrm{v}), 3288,3117$, 2930, 2850, $1630(\mathrm{~N}-\mathrm{H}$ d), $1522(\mathrm{C}=\mathrm{N} \mathrm{v}), 1414,1107,1017,836$, 735, 706, 483.

5-Amino-2-decyl-3-imino-1,2,4-thiadiazoline (4). Solution of 1-bromodecane (12.5 mL, $60.4 \mathrm{mmol})$ in $\mathrm{CH}_{2} \mathrm{Cl}_{2}, 3$ (2 g, 17.2 $\mathrm{mmol})$ and $\mathrm{MeOH}(80 \mathrm{~mL})$ was stirred with refluxing for 20 hours. After triethylamine $(4.2 \mathrm{~mL}, 30.2 \mathrm{mmol})$ was added to the reaction, the mixture was refluxed during 4 hours. The solvent was evaporated and the resultant product was washed with water. The desired product was extracted by $\mathrm{CHCl}_{3}$. The solvent was evaporated and a yellow oily was produced, which is soluble in low-polar organic solvents, and not soluble in water and hexane. Yield: $2 \mathrm{~g}$ (45 \%). $m / z$ (ESI) $257[\mathrm{M}+\mathrm{H}]^{+}$. IR (red glass) $v_{\max } \mathrm{cm}^{-1}: 3415(\mathrm{~N}-\mathrm{H}$ v), 2925, $2854\left(\mathrm{C}-\mathrm{H}_{\text {alk }}\right), 1623(\mathrm{~N}-\mathrm{H} \mathrm{d}), 1545(\mathrm{C}=\mathrm{N}$ v $), 1466,1395$, $1365,1162,1008,797,722,647,565$. UV-Vis $\left(\mathrm{CH}_{2} \mathrm{Cl}_{2}, c=1.64 \cdot 10^{-4}\right.$ $\left.\mathrm{mol} \cdot \mathrm{L}^{-1}\right) \lambda_{\max }(\lg \varepsilon) \mathrm{nm}: 263(3.72) .{ }^{1} \mathrm{H} \mathrm{NMR}\left(\mathrm{CDCl}_{3}, 500 \mathrm{MHz}\right) \delta_{\mathrm{H}}$ ppm: 7.36 (s, 1H, -NH), 5.43 (s, 2H, $\left.-\mathrm{NH}_{2}\right) ; 3.41$ (tr, $\left.2 \mathrm{H}, \mathrm{N}_{-} \mathrm{CH}_{2}-\right)$; 1.85 (m, 2H, N-CH $\left.-\mathrm{CH}_{2}-\right)$; 1.57-1.28 (m, 18H, $\left.-\mathrm{CH}_{2}\right) ; 0.88(\mathrm{tr}, 3 \mathrm{H}$, $\left.-\mathrm{CH}_{3}\right)$.

Bis(5-amino-1,3,4-thiadiazol-2-yl)ethane (5). A mixture composed of succinic acid (6) recrystallized from water with absorbent carbon ( $0.5 \mathrm{~g}, 4.2 \mathrm{mmol})$ and thiosemicarbazide (7) (0.77 g, $8.4 \mathrm{mmol})$ was dissolved in phosphorus oxychloride $(10 \mathrm{~mL})$. The temperature of the mixture was increased stepwise to $60{ }^{\circ} \mathrm{C}$ over 1 hour and was mixed for 20-25 min. The reaction mixture was poured out on crushed ice $(250 \mathrm{~g})$ and then was frozen. A white residue was filtrated and dried. Yield: $0.57 \mathrm{~g}(59 \%)$. $\mathrm{T}_{\text {melt }}>200{ }^{\circ} \mathrm{C}$. Found, \%: C 31.87, H 3.17, N 35.35, S 29.51. $\mathrm{C}_{6} \mathrm{H}_{8} \mathrm{~N}_{6} \mathrm{~S}_{2}$. Requires, \%: C 31.57, H 3.53, N 36.81, S 28.09. m/z (MALDI-TOF, CHCA): $229.00[\mathrm{M}+\mathrm{H}]^{+}$. IR (KBr) $v_{\max } \mathrm{cm}^{-1}: 3418,3254$ (N-H vas), 3144

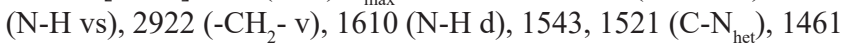
$\left(-\mathrm{CH}_{2}-\mathrm{d}\right), 1327,1273,1147,1075,814,703,594,520$.

$2,7,19,24$-Tet radec yl-3,8,15,20,25,32-hexaimino $5,10,17,22,27,34$-hexanitrilo-dibenzo $[k, z]-(3,7,11,15,19,23)$ hexaazacyclotetracosene (8). A mixture of 4 (0.16 g, $0.62 \mathrm{mmol})$ and $1(0.05 \mathrm{~g}, 0.31 \mathrm{mmol})$ was dissolved in phenol at $100-110{ }^{\circ} \mathrm{C}$ and reacted for 50 hours. The reaction was monitored by thin layer chromatography. The reaction mixture was washed by hot water from phenol, and then was extracted by hexane in a Soxhlet apparatus. The product was purified by column chromatography on silica gel, eluting impurities by $\mathrm{CH}_{2} \mathrm{Cl}_{2}: \mathrm{MeOH}: \mathrm{C}_{6} \mathrm{H}_{14}=10: 1: 3$, and the desired product was washed with methanol. A dark brown powder was obtained after removal of the solvent. This compound is soluble in acetone, methanol, but insoluble in water, hexane, and chloroform. Yield: $3.8 \mathrm{mg}$ (1\%). $\mathrm{m} / \mathrm{z}$ (MALDI-TOF, dithranol): $1213.4[\mathrm{M}]^{+}$. IR (KBr) $v_{\max } \mathrm{cm}^{-1}: 2924,2844\left(\mathrm{C}-\mathrm{H}_{\mathrm{alk}}\right), 1732,1595$ $(\mathrm{C}=\mathrm{N}$ v), 1468 (C-C v), 1390, 1259, 1112, 1042, 845, 794, 712, 601, 458. UV-Vis $\lambda_{\max }(\lg \varepsilon) \mathrm{nm}$ : benzene $\left(c=7.09 \cdot 10^{-5} \mathrm{~mol} \cdot \mathrm{L}^{-1}\right), 456$ (3.45); acetone $\left(c=4.5 \cdot 10^{-5} \mathrm{~mol} \cdot \mathrm{L}^{-1}\right), 456(4.00) ; \mathrm{H}_{2} \mathrm{SO}_{4} 480,745$.

7,22(23)-Di-tert-butyl-4:9,20:25-diimino-2:32,11:13,16:18, 27:29-tetranitrilo-33H,34H-1,12,17,28-tetrathiodibenzo[c, q](1,6,17,22)-tetraazacyclodotriacontene (9). A mixture of 5 (0.1 g, $0.44 \mathrm{mmol})$ and $2(0.09 \mathrm{~g}, 0.44 \mathrm{mmol})$ was dissolved in DMF. The temperature of reaction mixture was increased incrementally to boiling and then was refluxed for 75 hours. The desired product was obtained by addition of water. The resultant fine-dispersed powder was centrifuged, washed by ethanol to remove impurities, and dried under vacuum. The product is soluble in DMF. Yield: $0.07 \mathrm{~g}(20 \%) . \mathrm{m} / \mathrm{z}$ (MALDI-TOF, DHB): $799.20[\mathrm{M}+\mathrm{Li}+2 \mathrm{H}]^{+}$. IR $(\mathrm{KBr}) v_{\max } \mathrm{cm}^{-1}: 3421,3147,2903\left(\mathrm{C}-\mathrm{H}_{\mathrm{alk}}\right), 1682,1625(\mathrm{C}=\mathrm{N} \mathrm{v})$, 1563, 1524 (C-C v), 1431 (-CH - d), 1296, 1155, 1067, 979, 861, 550. UV-Vis (DMF, $\left.c=1.27 \cdot 10^{-4} \mathrm{~mol} \cdot \mathrm{L}^{-1}\right) \lambda_{\max }(\lg \varepsilon) \mathrm{nm}: 300$ (3.64). ${ }^{1} \mathrm{H}$ NMR ([D6]DMSO, $\left.500 \mathrm{MHz}\right) \delta_{\mathrm{H}} \mathrm{ppm:} 12.67$ (bs, 2H, =NH); 7.05-8.49 (m, 6H, - $\mathrm{CH}=) ; 2.98\left(\mathrm{~s}, 8 \mathrm{H},-\mathrm{CH}_{2}-\right) ; 1.35\left(\mathrm{~s}, 18 \mathrm{H},-\mathrm{CH}_{3}\right)$.

\section{Results and Discussion}

The synthesis of Mc 8 was carried out according to the Scheme 1.

Mass spectrum (MALDI-TOF, Dithranol) of reaction product was characterized by the presence of peaks corresponding to the molecular ions with $\mathrm{m} / z=494.6 ; 751.3$; 1211.4, which conform linear and cyclic products. The structure of this compound was shown in Figure 1.

The large number of compounds indicates that the reaction is nonselective. Probably, the formation of $\mathrm{Mc}$ of AABAAB-type passes through several intermediate stages and is a thermodynamically controlled process. Low yield of the desired product is explained by that the reaction did not have enough time to go to completion. It's possible that the first product of intermolecular condensation of fragments AA is formed. Then the accumulation of BAAB-product is occurred. At last the compound of AABAAB-type is formed.

Possibly, the rate of interaction of two similar alkylthiadiazoline molecule is much higher than the rate of interaction with 1,3-diiminoizoindoline (Scheme 2). This fact confirms the presence of these compounds in the reaction mixture.

The product that was characterized by mass spectrometry was refined by column chromatography. Mc 8 was obtained from methanol range. The solvent was evaporated, residue was dried under vacuum. The target compound was characterized by UV-vis, IR and mass spectra.

The compound $\mathbf{8}$ is conjugate system, which refutes Hückel rule of aromaticity. This fact explains absent of long wavelength absorption in UV-vis spectra and presence of strong absorption around $456 \mathrm{~nm}$ (Figure 2).

Interesting results was obtained by measuring spectra in concentrated sulfuric acid (Figure 3). The strong band of absorption shifts in long wavelength range by $24 \mathrm{~nm}$ and new band appears with maximum at $745 \mathrm{~nm}$. The dilution of 
Macroheterocyclic Compounds with 1,2,4- and 1,3,4-Thiadiazole Fragments

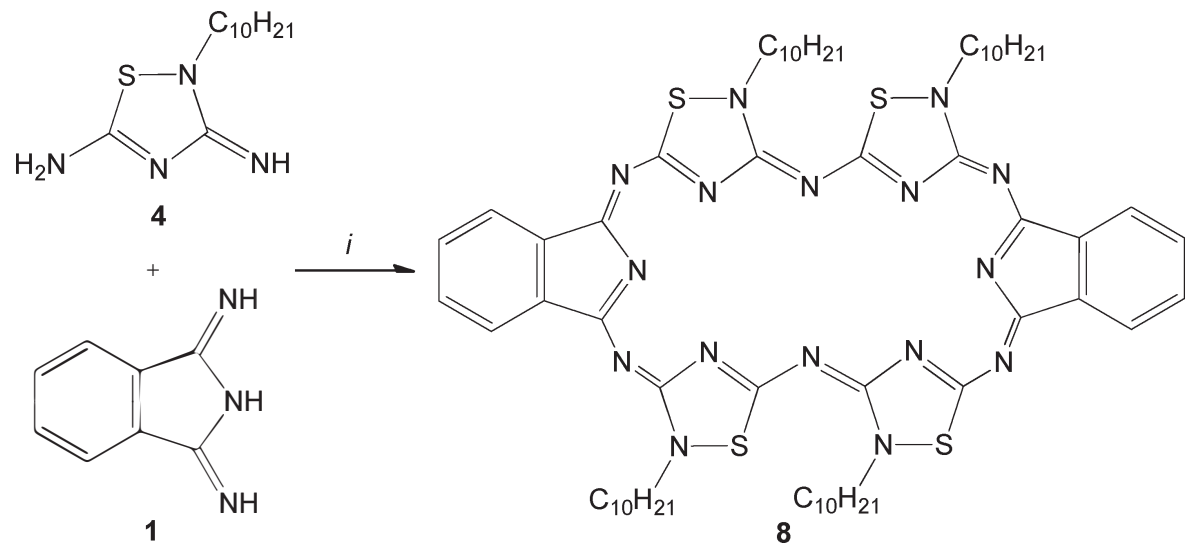

$i: \mathrm{PhOH}, \mathrm{t}=100-110^{\circ} \mathrm{C}, 55 \mathrm{~h}$; ratio $4: 1=2: 1$

Scheme 1.

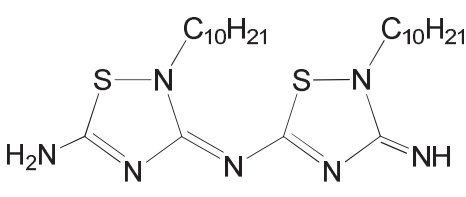

AA

Exact Mass: 495,32

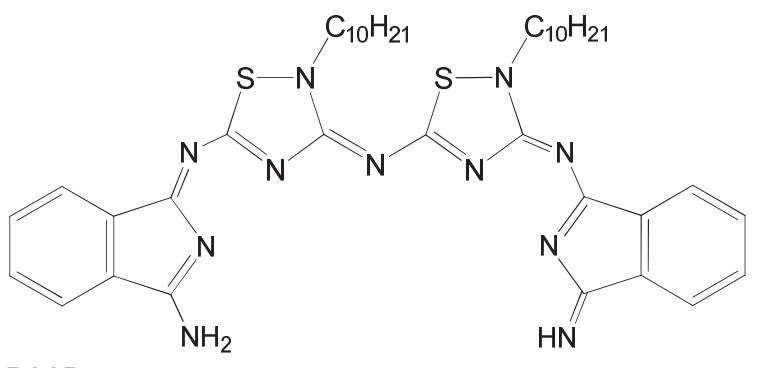

BAAB

Exact Mass: 751,39

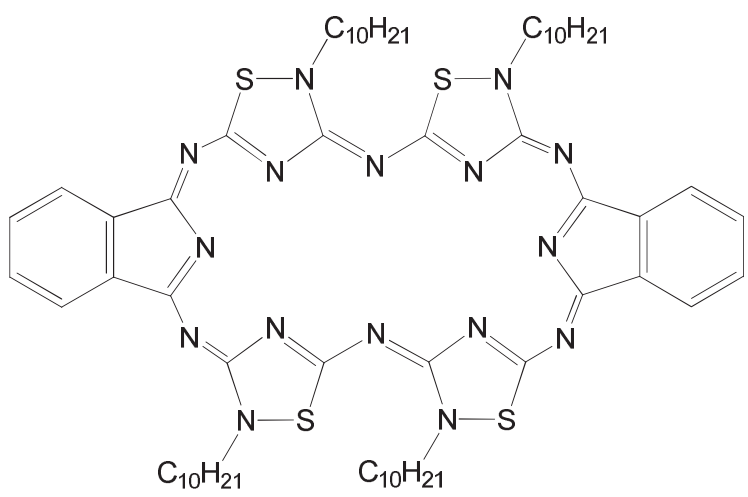

AABAAB

\section{Exact Mass: 1212,66}

Figure 1. The structure of linear and cyclic compounds.

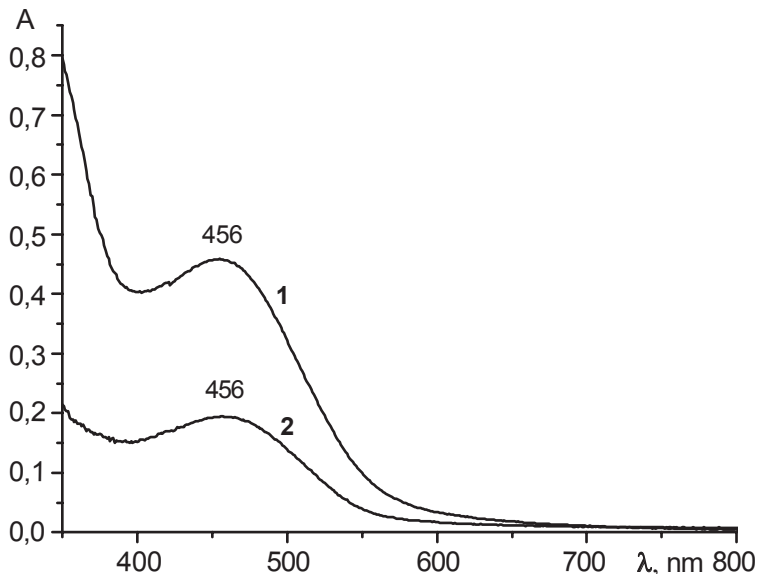

Figure 2. The UV-vis spectra of 8: 1 - acetone $\left(c=4.5 \cdot 10^{-5}\right.$ $\left.\mathrm{mol} \cdot \mathrm{L}^{-1}\right), 2$ - benzene $\left(c=7.09 \cdot 10^{-5} \mathrm{~mol} \cdot \mathrm{L}^{-1}\right)$.

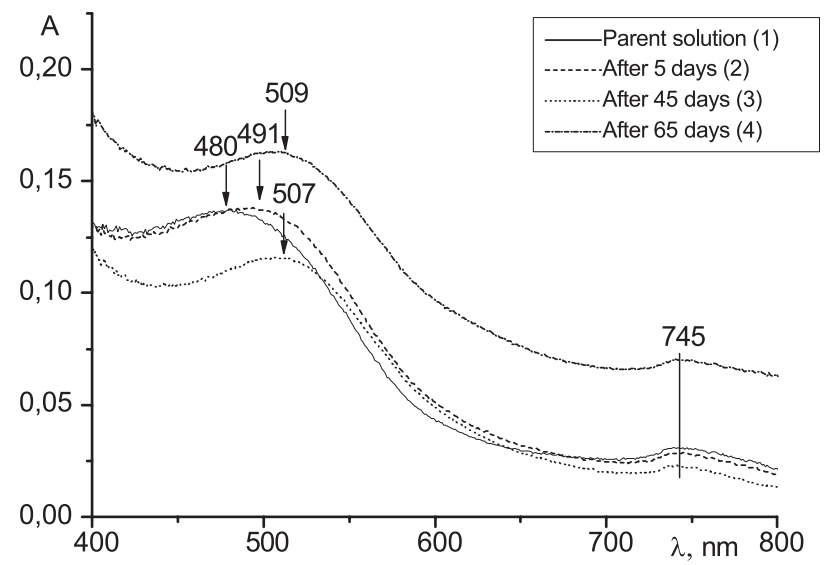

Figure 3. The UV-vis spectra of 8: 1 - concentrated $\mathrm{H}_{2} \mathrm{SO}_{4}$, 2-4 - diluted $\mathrm{H}_{2} \mathrm{SO}_{4}$.

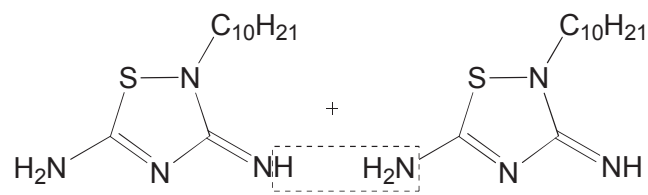

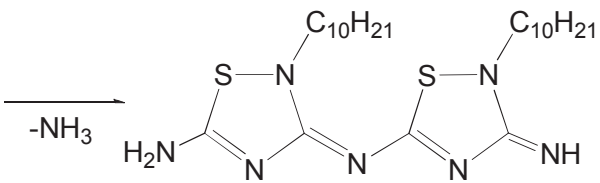

Scheme 2. 
sulfuric acid solution results in bathochromic shift of absorption band, which in process of time increases. So maximum of absorption was recorded at $509 \mathrm{~nm}$ after 65 days.

This spectral change confirms step by step protonation of nuclear center of macrocyclic ligand.

Thus, the obtained compound $\mathbf{8}$ is stable as in concentrated, so dilute sulfuric acid for several months, what is not typical for Mc, which are destroyed during $30 \mathrm{~min}$.

The dark suspension was formed at reprecipitation from solution of $\mathbf{8}$ in concentrated sulfuric acid. The intensity of the absorption band appeared at $456 \mathrm{~nm}$ again, but small inflection at $745 \mathrm{~nm}$ saves, what can be explained by the presence of residue of the protonated form.

Macroheterocyclic compound 9 was obtained on the basis of binuclear diamine $\mathbf{5}$, which was prepared correspondingly to the Scheme 3 .

The signal at $229.00 \mathrm{~m} / \mathrm{z}$ in the mass-spectrum (MALDI-TOF, CHCA) of $\mathbf{5}$ corresponds to $[\mathrm{M}+\mathrm{H}]^{+}$molecular ion. In the IR spectrum of compound $\mathbf{5}$, a series of bands at 3254 , 3144 and $1610 \mathrm{~cm}^{-1}$ can be characterized as asymmetrical, symmetrical stretching and deformation vibrations of the amine groups. The bands at 2922 and $1461 \mathrm{~cm}^{-1}$ correspond to $\mathrm{C}-\mathrm{H}$ vibrations of ethyl groups, what is in agreement with the literature. ${ }^{[23]}$

Macroheterocyclic compound on the basis of bis(5amino-1,3,4-thiadiazol-2-yl)ethane $\mathbf{5}$ was obtained by Scheme 4.

The mass spectrum (MALDI-TOF, DHB) of compound 9 is characterized by the presence of a peak corresponding to the molecular ion with $\mathrm{m} / \mathrm{z}=799.20$ in form $[\mathrm{M}+\mathrm{Li}+2 \mathrm{H}]^{+}$. The ${ }^{1} \mathrm{H}$ NMR spectrum of compound 9, measured in DMSO- $d_{6}$, reveals a signal at $1.35 \mathrm{ppm}$, which can be assigned to the protons of tert-butyl groups. The multiplets at 8.49-7.05 ppm arise due to the resonance of the protons of benzene rings, and the singlets at 12.67 and $2.98 \mathrm{ppm}$ are characteristic of the protons of the pyrrolic fragments and ethyl groups, respectively.
Quantum chemical calculations of a model compound, which has the tert-butyl groups in the isoindole fragments ommitted, were performed to determine the steric and electronic structure of Mc 9. Full optimization of geometrical parameters was carried out by the density functional theory using hybrid functional B3LYP and basis set 6-31G $(\mathrm{d}, \mathrm{p}){ }^{[24]}$ Preparation of the initial geometry, processing and visualization of the results of calculations were performed using programs ChemCraft ${ }^{[25]}$ and Mercury 3.7. Mc 9 can exhibit several conformers, some of which are shown in Figure 4. Quantum chemical calculations show that the most energetically favorable conformer is $\mathbf{9 a}$. This structure is lower in energy by $6.13 \mathrm{kcal} / \mathrm{mol}$, than $\mathbf{9 b}$. These data agree well with the published data for the compounds of ABABAB-type, in which there is an inversion of the three thiadiazole rings with the sulfur atoms pointing outward from the inner cavity. ${ }^{[14]}$
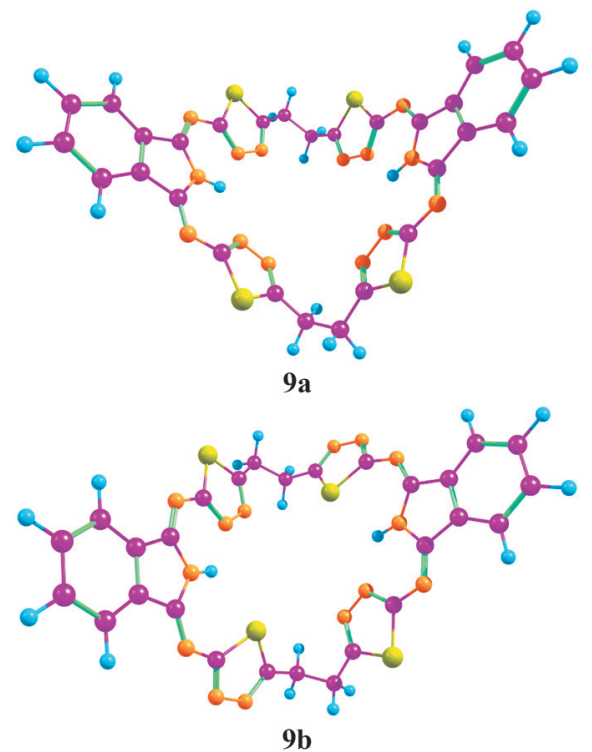

Figure 4. Structure of some conformers of 9.<smiles>NNC(N)=S</smiles>
i: $\mathrm{POCl}_{3,} \mathrm{t}=60{ }^{\circ} \mathrm{C}, \tau=20-25 \mathrm{~min}$

Scheme 3.<smiles>CC(C)(C)c1ccc2c(c1)C(=N)NC2=Nc1nnc(CCc2nnc(/N=C3\NC(=Nc4nnc(CCc5nnc(/N=C6\NC(=N)c7ccc(C(C)(C)C)cc76)s5)s4)c4cc(C(C)(C)C)ccc43)s2)s1</smiles>

Scheme 4. 
Calculations showed that compound 9a has non-planar structure. The $\mathrm{H}$-atoms of imino groups of isoindole moieties aligned toward the $\mathrm{N}$-atoms of thiadiazole rings. As a result, hydrogen bonds $(2.148-2.153 \AA)$ between the two fragments consisting of two thiadiazoles and one isoindoline moieties are formed. These fragments have a nearly planar structure, but the sulfur atom deviates thiadiazole from the planarity of the fragment. The angle between these fragments is $82^{\circ}$, while in similar compounds with bis(5-amino-1,2,4-triazole3 -il)methane units, the angle between planes is $139.9^{\circ}$. [26] This fact can be explained by the increased structural flexibility of the ethyl bridge (Figure 5).

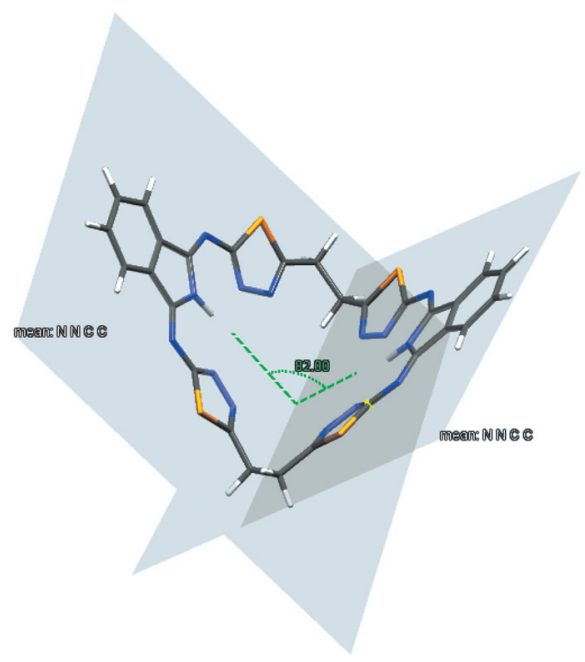

Figure 5. The structure of calculated model compound.

\section{Conclusions}

Macroheterocyclic compounds of AABAAB-type were obtained by interaction of thiadiazole diaminoderivatives and 1,3-diiminoizoindoline or tert-butyldiiminoizoindoline. It was determined that compound $\mathbf{8}$ possesses stability in sulfuric acid. Quantum chemical calculations of the model compound showed that the structure of compound 9 corresponds to the structure of similar ABABAB-type Mcs, described in literature.

Acknowledgements. The work was carried out in accordance with the state task of the Ministry of Education and Science (Project part № 1677).

\section{References}

1. Preihs C., Arambula J.F., Lynch V.M., Siddik Z.H., Sessler J.L. Chem. Commun. 2010, 46, 7900-7902.

2. Lammer A.D., Cook M.E., Sessler J.L. J. Porphyrins Phthalocyanines 2015, 19, 398-403.
3. Yoon Z.S., Cho D.G., Kim K.S., Sessler J.L., Kim D. J. Am. Chem. Soc. 2008, 130, 6930-6931.

4. Brinkhaus L., Katsukis G., Malig J., Costa R.D., GarciaIglesias M., Vázquez P., Torres T., Guldi D.M. Small 2013, 9, 2348-2357.

5. Danilova E.A., Melenchuk T.V., Trukhina O.N., Zakharov A.V., Islyaikin M.K. Macroheterocycles 2010, 3, 33-37.

6. Danilova E.A., Bumbina N.V., Islyaikin M.K. Macroheterocycles 2011, 4, 47-49.

7. Eckert A.K., Trukhina O.N., Rodriguez-Morgade M.S., Danilova E.A., Islyaikin M.K., Torres T. Mendeleev Commun. 2010, 20, 192-194.

8. Lomova T.N., Mozhzhukhina E.G., Danilova E.A., Islyaikin M.K. Russ. J. Phys. Chem. 2009, 83, 1694-1700.

9. Danilova E.A. Synthesis, tructure and properties of the azolmacroheterocyclic compounds. Diss. Doc. Chem. Sci. Ivanovo: ISUCT, 2011. 393 p. (in Russ.).

10. Islyaikin M.K., Danilova E.A., Yagodarova L.D., RodríguezMorgade M.S., Torres T. Org. Lett. 2001, 3, 2153-2156.

11. Zakharov A.V., Shlykov S.A., Bumbina N.V., Danilova E.A., Krasnov A.V., Islyaikin M.K., Girichev G.V. Chem. Commun. 2008, 30, 3573-3575.

12. Zakharov A.V., Shlykov S.A., Danilova E.A., Krasnov A.V., Islyaikin M.K., Girichev G.V. Phys. Chem. Chem. Phys. 2009, $11,8570-8579$.

13. Zhabanov Y.A., Zakharov A.V., Shlykov S.A., Trukhina O.N., Danilova E.A., Koifman O.I., Islyaikin M.K. J. Porphyrins Phthalocyanines 2013, 17, 220-228.

14. Trukhina O.N., Rodríguez-Morgade M.S., Wolfrum S., Caballero E., Snejko N., Danilova E.A., Gutiérrez-Puebla E., Islyaikin M.K., Guldi D.M., Torres T. J. Am. Chem. Soc. 2010, 132, 12991-12999.

15. Lomova T.N., Suslova E.E., Danilova E.A., Islyaikin M.K. Russ. J. Phys. Chem. 2005, 79, 201-206.

16. Lomova T.N., Mozhzhukhina E.G., Danilova E.A., Islyaikin M.K. Russ. J. Coord. Chem. 2006, 32, 837-840.

17. Trukhina O.N., Zhabanov Y.A., Krasnov A.V., Danilova E.A., Islyaikin M.K. J. Porphyrins Phthalocyanines 2011, 15 , 1287-1291.

18. Filatov M.S., Trukhina O.N., Rodríguez-Morgade M.S. Islyaikin M.K., Koifman O.I., Torres T. J. Porphyrins Phthalocyanines 2014, 18, 1014-1020.

19. Filatov M.S., Kydayarova T.V., Danilova E.A., Islyaikin M.K. Izv. Vyssh. Uchebn. Zaved., Khim. Khim. Tekhnol. 2014, 57(7), 21-25 (in Russ.).

20. Baumann F., Bienert B., Rosch G., Vollmann H., Wolf W. Angew. Chem. 1956, 68, 133-168.

21. Mihalenko S.A., Barkanova S.V. Lebedev O.L. Zh. Obchsh. Khim. 1971, 41 (12), 2735-2739 (in Russ.).

22. Danilova E.A., Melenchuk T.V., Trukhina O.N., Islyaikin M.K. Macroheterocycles 2010, 3, 68-81.

23. Ashutosh B., Ankur J., Kumar N.R., Sonia G., Niharika S., Vivek D., Pramod S. Int. J. Pharm. Scie. Drug Research 2009, $1,207-210$.

24. Granovsky A.A. Firefly version 8.1.0, build number 9035 , http://classic.chem.msu.su/gran/firefly/index.html

25. Zhurko G.A. ChemCraft version 1.6, build 312, http://www. chemcraflprog.com/index.html

26. Filatov M.S. Synthesis and properties of the azolmacroheterocyclic compounds with expanded coordination cavity. Diss. Cand. Chem. Sci. Ivanovo: ISUCT, 2014. 140 p. (in Russ.). 